\title{
Reactive arthritis before and after the onset of the COVID-19 pandemic
}

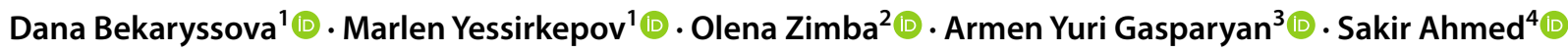

Received: 31 January 2022 / Revised: 26 February 2022 / Accepted: 28 February 2022 / Published online: 5 March 2022

(c) The Author(s), under exclusive licence to International League of Associations for Rheumatology (ILAR) 2022

\begin{abstract}
Most accepted definitions of reactive arthritis (ReA) consider it a type of spondyloarthritis (SpA) precipitated by a gut or urogenital infection. A wider definition considers any arthritis that occurs after a mucosal surface infection as ReA. There is limited consensus regarding a working definition, status of HLA-B27, or even classification criteria for ReA. This may also contribute to a lack of systemic studies or clinical trials for ReA, thereby reducing further treatment recommendations to expert opinions only. The emergence of post-COVID-19 ReA has brought the focus back on this enigmatic entity. PostCOVID-19 ReA can present at extremes of age, appears to affect both sexes equally and can have different presentations. Some present with small joint arthritis, others with SpA phenotype-either with peripheral or axial involvement, while a few have only tenosynovitis or dactylitis. The emergence of post-vaccination inflammatory arthritis hints at similar pathophysiology involved. There needs to be a global consensus on whether or not to include all such conditions under the umbrella of ReA. Doing so will enable studies on uniform groups on how infections precipitate arthritis and what predicts chronicity. These have implications beyond ReA and might be extrapolated to other inflammatory arthritides.

\section{Key Points}

- Classical reactive arthritis (ReA) has a spondyloarthritis phenotype and is preceded by symptomatic gut or urogenital infection

- The demonstration of antigen and nucleic acid sequences of pathogens in synovium has blurred the difference between invasive arthritis and reactive arthritis

- Post-COVID-19 ReA has a transient phenotype and can have different presentations. All reported cases are self-limiting

- The large amount of literature reporting post-COVID-19 ReA calls for introspection if the existing definitions of ReA need to be updated.
\end{abstract}

Keywords Infection-induced arthritis · Reactive arthritis $\cdot$ SARS-CoV-2 arthritis $\cdot$ Spondyloarthritis

\section{Introduction}

Reactive arthritis (ReA) is classically considered a sub-type of spondyloarthritis $(\mathrm{SpA})$ that is precipitated after a gastrointestinal or genitourinary infection [1]. The usual presentation is monoarticular or oligoarticular arthritis involving large joints that occurs around 2-4 weeks after an infection [2]. However, the term has been used in a wider context of an immune-mediated arthritis that may occur after any infection. The primary concept is that there is no direct invasion

Sakir Ahmed

sakir005@gmail.com

Extended author information available on the last page of the article of the joints by any pathogen but the arthritis occurs as a result of induced changes in the immune system.

The proposed definitions of ReA have under the umbrella of SpA, be it under the Amor or the European Spondyloarthropathy Study Group (ESSG) proposed criteria for "Spondyloarthropathy" [3] or the currently used ASAS (ASsessment in Ankylosing Spondylitis working group) criteria for peripheral SpA [4]. According to these definitions, the pathognomic features of $\mathrm{SpA}$ are required to label a patient as having ReA. These include sacroiliitis, uveitis, dactylitis, enthesitis, and HLA-B27 or family history of SpA, psoriasis, or uveitis $[4,5]$.

ReA allows us a distinctive opportunity to scrutinize and learn how an infective trigger precipitates an autoimmune phenomenon. A majority of ReA resolves within a 
few weeks to a few months. The rest assume a chronic form indistinguishable from other chronic autoimmune arthritides [6]. Thus, it also provides an opening to understand how the autoimmune process becomes self-sustaining and chronic.

ReA is a predominant problem of low-to-middle income countries where gut and urinary tract infections abound. Though it is reported from high-income countries, the phenotype is usually limited to arthralgia, tenosynovitis, dactylitis or often notso-severe arthritis. The phenotype seen in the tropics is much different with the rapid development of secondary osteoarthritis or even evolution into ankylosing spondylitis [7]. However, with the COVID-19 pandemic, there are a lot of reports of postCOVID-19 ReA, re-igniting interest in this entity worldwide.

This perspective aims to explore how the concept of ReA has evolved over the last century, touching upon similar entities and finally how the COVID-19 pandemic is coercing us to re-look into the definitions of this enigmatic malady.

\section{Search strategy}

We have adhered to recommendations for narrative review searches [8]. We searched through Scopus and LitCovid/PubMed databases [9]. Non-English sources have not been consulted. Conference abstracts or non-peer reviewed sources were not included. To avoid confusion, we used the MeSH keyword "reactive arthritis" that includes "post infectious arthritis" for searches through LitCovid/PubMed. For Scopus, we used "reactive arthritis" OR "post infectious arthritis" in the search string.

\section{History of ReA}

The first descriptions of a post-infectious arthritis were made during the time of the First World war by Fiessinger and Leroy [10]. However, it was more commonly known with the eponym from a Nazi doctor who had first described a triad of urethritis, conjunctivitis, and arthritis. However, since he was convicted of war crimes, the eponym is not encouraged [11]. Also, a similar triad had already been described almost a century ago by Sir Benjamin Brodie in five cases [12].

More than half a century after the First World War, the concept of ReA was established as a non-purulent arthritis that occurred after a gastrointestinal infection without the direct invasion of the bacteria into the joints [13]. This concept was first contradicted by the finding of Chlamydia elementary bodies in the synovial cells of patients with ReA [14]. The tug of war over this concept has kept on going for a few decades. Now, it is clear that the entire live organism is not found in the joint but some antigen or genetic material, possibly carried by endosomes, may persist in the joint and lead to a sustained inflammatory reaction [15].

\section{Current definitions and limitations}

As the definition of ReA evolved, more and more entities were proposed for inclusion such as Lyme disease, gonococcal arthritis, post-streptococcal reactive arthritis, and rheumatic fever [16]. While it is true that Lyme disease and gonococcal arthritis may not fulfil the classical Koch's postulates to be defined as an "infection," both have unique characteristics clinical features. Clubbing them with $\operatorname{Re} A$ will neither help in the management nor further research. Similarly, the differences between ReA and post-streptococcal reactive arthritis are elaborated elsewhere [17].

The most commonly used definition of ReA has been provided by Braun and associates $[18,19]$. This definition requires monoarthritis or oligoarthritis preceded by symptomatic diarrhoea or urethritis. For "definite" ReA to be diagnosed by the Braun criteria, an organism with known association with ReA needs to be demonstrated by culture or PCR. Even while these classification criteria were formulated, there was a lack of agreement on various points like the relationship of HLA-B27 with $\operatorname{ReA}$, the existence of $\operatorname{ReA}$ without arthritis, or whether it should include only spondyloarthritis presentations or any arthritis [18]. More and more organisms are being added to the list of potential precipitants of ReA [20]. Also, the definition by Braun et al. does not consider the entity of "post-vaccination ReA."

The American College of Rheumatology (ACR) or the European Alliance of Associations for Rheumatology(EULAR) do not have separate practice guidelines pertaining to $\mathrm{ReA}$ as possibly the rheumatologists in Europe or the United States do not see severe cases of $\operatorname{ReA}[21-23]$. The incidence is apparently declining in most high-income countries [24]. However, the rest of the world that depend on the ACR and EULAR recommendations may find this gap challenging. For example, Latin America had the largest proportion of patients with "peripheral spondyloarthritis" [25]. ReA from India has arthritis as the predominant feature in $95 \%$ of patients [26] while a report from Finland showed only arthralgia in two and arthritis in none of 17 patients with post-Escherichia coli musculoskeletal conditions [23]. Thus, there seem to be great differences in how clinicians from different parts of the world view ReA.

Only a small percentage of patients who have infections with organisms such as Campylobacter, Salmonella, Shigella, or Yersinia develop ReA [27]. Similarly, amongst millions who have developed SARS-CoV-2 infection, only a minor proportion develops arthritis. Understanding this may help unearth new verities about the immune system and tolerance mechanisms.

\section{Clinical phenotype of post-COVID-19 ReA}

\section{Phenotype}

Post COVID-19 arthritis more commonly has a rheumatoid like phenotype affecting the wrists, ankles, and small 
joints of hands and feet. However, a spondyloarthritis-like presentation with axial involvement has also been reported [28]. It can also present as classical ReA with lower limb predominant oligoarthritis [29]. Isolate monoarthritis of a single metacarpophalangeal joint has also been reported [30]. Table 1 summarizes the different phenotypes, treatments given, and outcomes in various case reports of postCOVID-19 reactive arthritis from across the world.

\section{Age and gender}

The initial reports of post-COVID-19 ReA were in men past 50 years of age $[31-33,35]$. This is in contrast to the classical ReA that is most common between 15 and 40 years of age. Again, at least three cases of post-COVID-19 ReA have also been reported in the paediatric age group [41, 45]. Unlike classical ReA, gender distribution appears equal between males and females. However, the total number of reported cases is too small for conclusive comments.

\section{Treatment and outcome}

The majority of the patients had responded to non-steroidal anti-inflammatory drugs (NSAIDs) while some received intra-articular steroids or rapidly tapered oral steroids (Table 2). Where outcomes are reported, usually, there was a response within the first week and the steroids /NSAIDs could be tapered down after 4 weeks. Only patients with rheumatoid arthritis-like phenotype with anti-citrullinated peptide antibodies had a chronic course and had to be given methotrexate [48-50].

Thus, the phenotype and outcomes of post-COVID-19 ReA appear to be different from those of classical ReA. These differences are summarized in Table 2.

\section{Reactive arthritis after COVID-19 vaccination}

Vaccination-induced autoimmunity is a concern since vaccines stimulate the immune system [51]. The first published case of ReA post-COVID-19 vaccination was reported in a 23-year-old woman after the inactivated Sinovac-CoronaVac vaccine [52]. We could identify a total of seven cases of inflammatory arthritis reported post-vaccination (Table 3).

\section{Other post-COVID-19 inflammatory arthritis}

We have reviewed post-COVID-19 rheumatic diseases at an earlier stage of the pandemic [57]. Post-COVID-19 peripheral nerve entrapment syndromes like carpal tunnel or tarsal tunnel syndromes have been hypothesized to be either due to localized demyelination, microangiopathy involving the vasa nervosum or an immune phenomenon targeting the adjacent synovial sheath [58]. An interesting group is the patients who have clinical phenotype and antibodies suggestive of rheumatoid arthritis developing post-COVID-19. These patients developed anti-cyclic citrullinated peptide antibody-positive arthritis after documented COVID-19 infection [48-50].

One concern was whether vaccination would cause a flare in persons with pre-existing autoimmune diseases [51]. Cases with flares of RA temporarily related to vaccination have been reported [59]. However, in a cohort of 724 patients with autoimmune rheumatic disease, only 4 patients had complained of a flare in joint pain. This was managed with NSAIDs and lasted less than a week [60].

In a cohort of 5493 RA patients from Hong Kong, a propensity-score weighted multivariate analysis did not show any association with COVID-19 vaccination and flare of RA [61].

\section{Chronic arthritis after other viral infections}

Several viruses are associated with acute polyarthritis that lasts less than 6-8 weeks [62]. In a small proportion of cases, such viral arthritis may become chronic such as in the case of HIV (Human Immunodeficiency Virus), Hepatitis B and $\mathrm{C}$ viruses [63, 64], parvovirus B19, and Chikungunya [65]. Some authors have argued that it may be better to label "COVID-19 associated arthritis" rather than "COVID-19 ReA" [66]. COVID-19 can also possibly precipitate arthritis in a susceptible individual. There is a case report of a lady with psoriasis and inflammatory bowel disease who developed arthritis post-COVID-19 infection [67].

Post-chikungunya or Parvovirus B-19 there can be an onset of arthritis indistinguishable from rheumatoid arthritis $[68,69]$. A similar phenomenon has been reported postCOVID-19 too [48-50]. However, such anti-citrullinated antibody-positive RA has been reported only in 3 cases to date. The possibility of a coincidence cannot be excluded looking at the high incidence of COVID-19 infections and the not uncommon incidence of RA, but the point in support of a "reactive" arthritis is that the arthritis is seen after the acute COVID-19 infection. It is self-limiting. Had it been a direct viral arthritis, the synovitis should have occurred during the seroconversion phase. In acute COVID-19 infection, though arthralgia is common, documented arthritis has been rarely reported.

\section{Possible pathogenic mechanisms}

Viruses have been long implicated in the breakdown of immune tolerance and precipitation of autoimmune disease [70]. SARS-CoV-2 activates CD14+ monocytes and PD-L1 + neutrophils via the Osteopontin-mediated inhibition of Interleukin-10. This pathway is involved in rheumatoid arthritis and thus provides a common pathway for the 


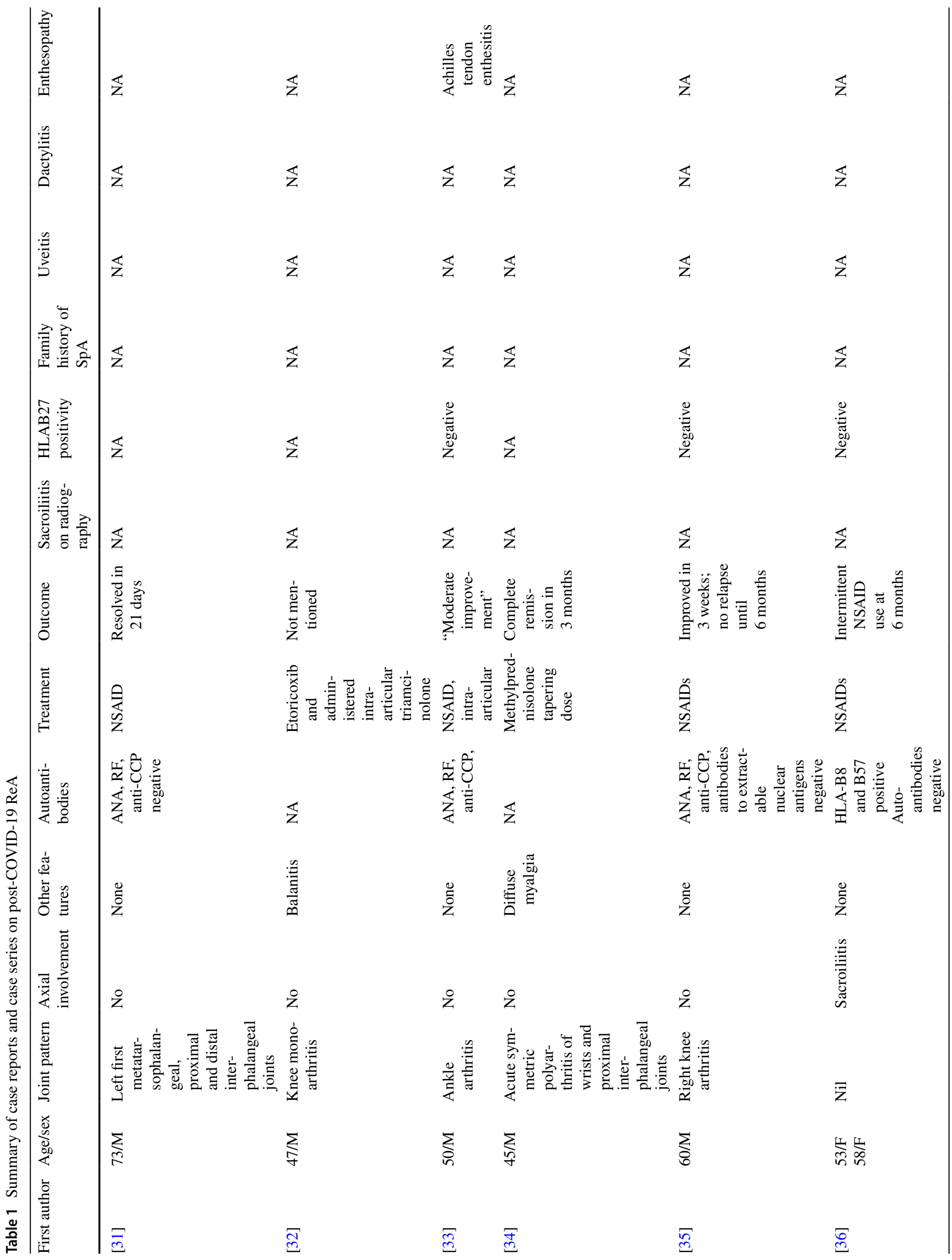




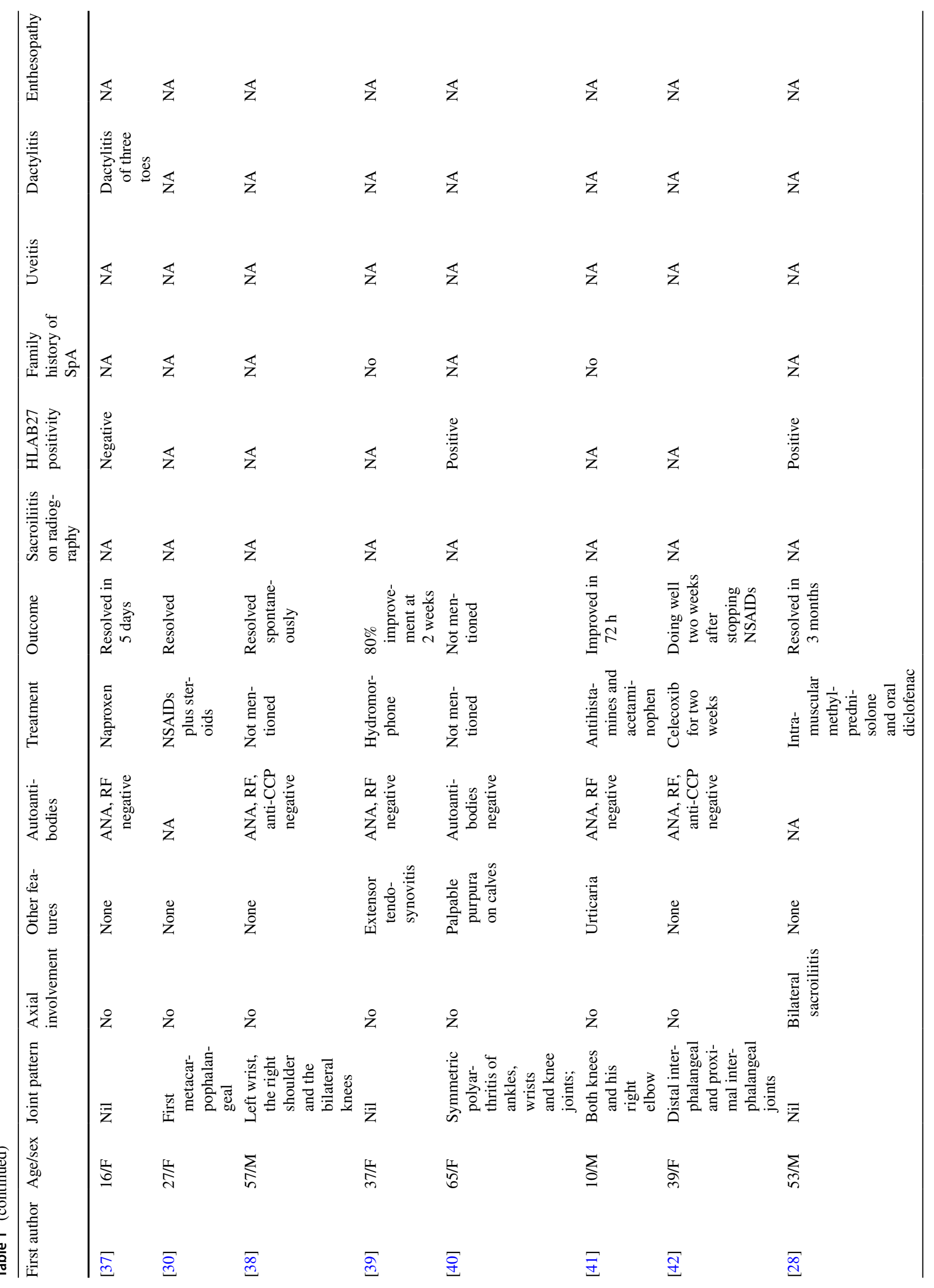




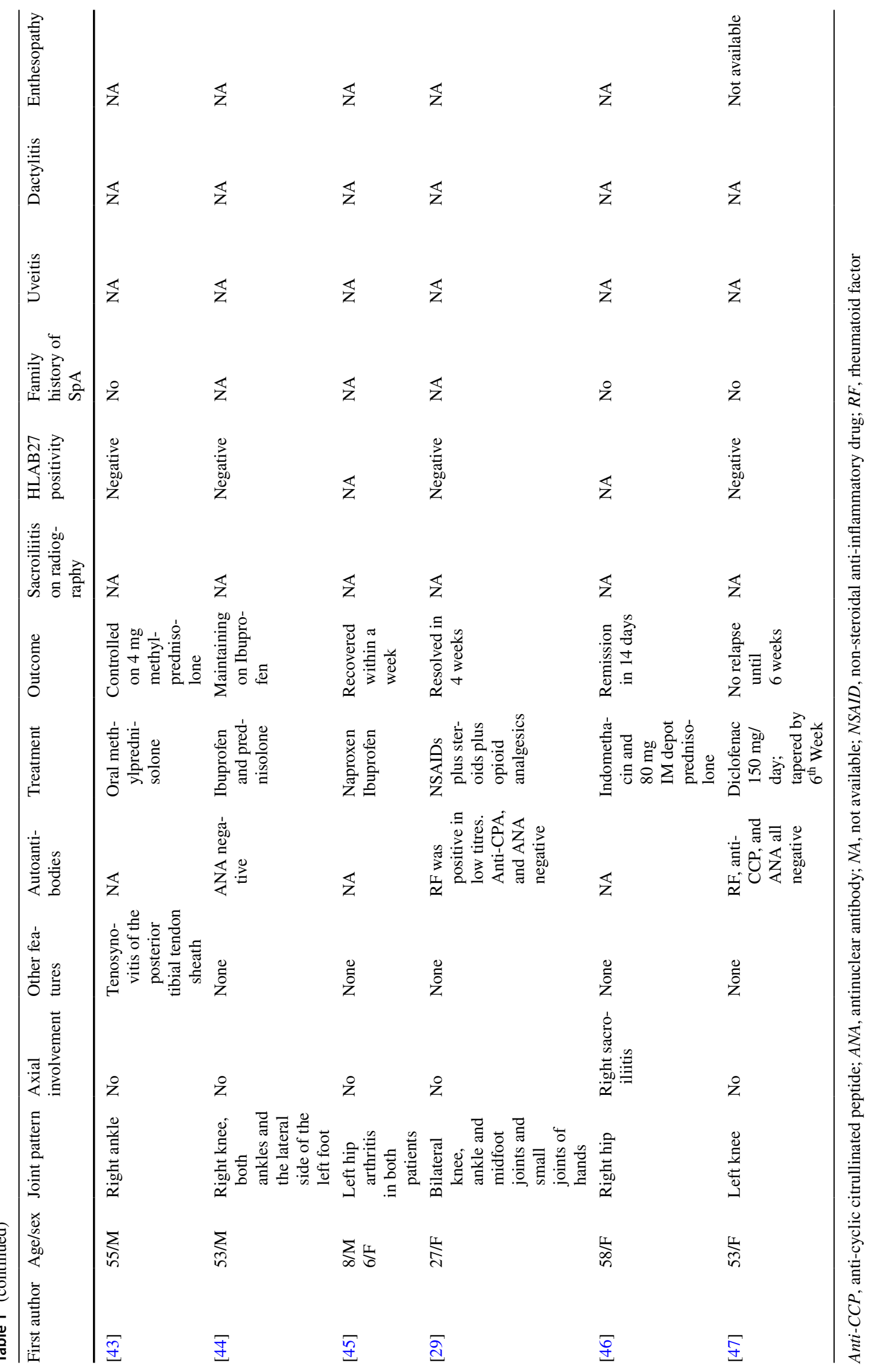


evolution of inflammatory arthritis [71]. In Chikungunya viral infection, a prominent role of monocytes and anti-viral responses such as interferons has been postulated [72].

Interferon (IFN)-related pathways have been implicated in COVID-19 [73, 74] and these have a role in the initiation of rheumatoid arthritis. The TNF (Tumor Necrosis Factor)induced animal models of rheumatoid arthritis are dependent on IFN and IFN response elements such as the IRF1 (interferon regulatory factor 1) transcription factor [75].

Also, various autoantibodies have been reported in COVID-19 [76]. Some of these might have pathological potential and if they persist after the infection, they may lead to rheumatic manifestations like arthritis. At least 15 different autoantibodies have been described in COVID-19 and 34 human peptides have similarities with SARS-CoV-2 proteins [77]. This may have implications for molecular mimicry in COVID-19.

\section{Timelines of classic and post-COVID-19 reactive arthritides}

Classical ReA is self-limiting in two-thirds of cases, but can damage the joints even in such a short period. Chronic ReA can have much worse sequelae. In the case of postCOVID-19 ReA, the manifestations appear more transient and self-limiting. This appears more similar to post-streptococcal ReA rather than classical ReA [17]. Also, some cases of post-COVID-19 ReA have different antibodies. There is a possibility that these may evolve into classifiable rheumatic diseases such as rheumatoid arthritis or lupus [57].

It is not necessary that all arthritis occurring postCOVID-19 should be reactive arthritis. The alternative is that it may be late-onset viral arthritis with actual invasion of the synovial space with the virus [78]. We could identify one study that reported the detection of SARS-CoV-2 RNA in a patient with wrist arthritis that had appeared 15 days after diarrhoea and upper respiratory tract symptoms [79]. However, other cases have not found such evidence [80]. Moreover, a post-mortem study also failed to find any viral RNA in synovial fluid or bone tissue in five patients who had died of COVID-19 [81].

\section{Limitations}

One limitation of this review is that the search strategy could miss cases of SARS-CoV-2 associated arthritis if the words "reactive" or "post-infectious" were not used. However, the main focus of the review was to assess how clinicians perceive and use the concept of reactive arthritis rather than only assessing SARS-CoV-2 associated arthritis.

\section{Refining definitions for $\operatorname{ReA}$}

The definitions of ReA have been evolving gradually over the last half-century. Nevertheless, an ideal working definition still eludes us. Since this entity is not very common in high-income countries, there are possibly limited guidelines for this entity. The evidence base for treatment is also weak. The first and foremost requirement to fill in these deficiencies is a strong and universal definition of ReA.

Table 2 Differences between classical and post-COVID-19 reactive arthritis

\begin{tabular}{lll}
\hline & "Classical" reactive arthritis & Post-COVID-19 reactive arthritis \\
\hline Age & 15-40 years predominantly & Above 45 years predominantly, but reported in all ages \\
Gender & Male preponderance & Equal male-female distribution \\
Precipitating factor & Gut or urogenital infection & Respiratory tract infection \\
Inciting agent & Bacteria & Virus \\
Phenotype & Spondyloarthritis-like & Multiple phenotypes \\
& -Axial involvement & \\
Joint predilection & -Lower limb predominant oligoarthritis & \\
Chronicity & Large joints & Small joints \\
Management & 1/3rd become chronic (lasts beyond 3 months) & Most resolve within 2 weeks to 3 months \\
Extra-articular manifestations steroids with or without NSAIDs is & Usually, low dose ster \\
& Treated as other spondyloarthritis (limited evidence & sufficient (limited evidence base) \\
& Dase) & Unknown/limited \\
& Enthesitis & \\
& Skin & \\
& Uveitis & \\
& Inflammatory bowel disease &
\end{tabular}




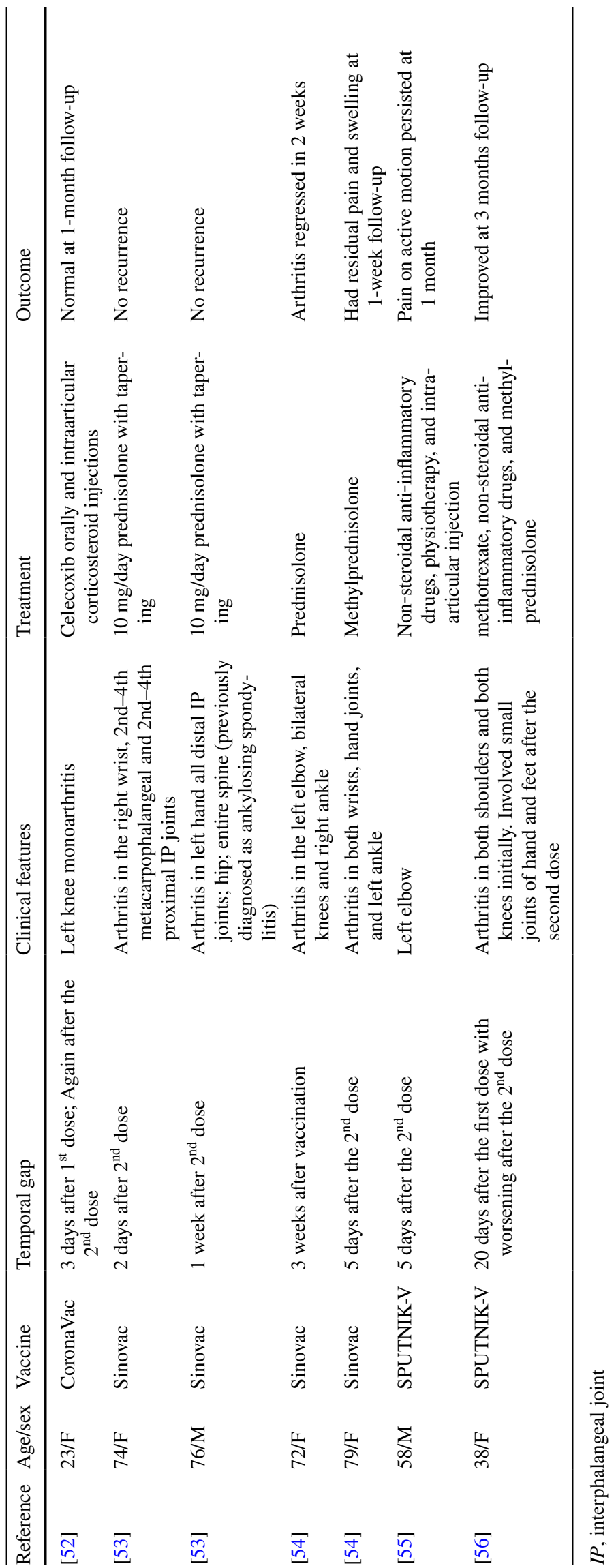


Though there is a definite association between COVID19 and arthritis, the scientific rigor to establish causality is incomplete yet. Thus, any new definition should allow for reasonable doubt, but still be sufficiently solid to further studies in the field.

The advent of ultrasound in the detection of enthesitis can enable a more objective definition [82]. Also, radiographic features such as new bone formation at the site of enthesitis can be a possible marker [83]. Radiographic changes are late but ultrasound diagnosis can be early with validated OMERACT (Outcome Measures in Rheumatology Clinical Trials) definitions available [84].

\section{Conclusion}

The emergence of post-COVID-19 ReA and possibly postvaccination $\mathrm{ReA}$ is forcing a paradigm shift in how we perceive this entity. Post-vaccination autoimmune diseases are being reported [85]. This leads to the question of whether individuals with genetic predisposition such as HLA-B27 positivity need to be segregated for different vaccines [52].

As the SARS-CoV-2 pandemic is transformed into an endemic due to wide-spread vaccination and emergence of less virulent strains, it will be interesting to study how this affects emergence of COVID-19 associated autoimmune conditions including ReA.

Finally, post-infectious arthritis may hold the key to understanding how the chronicity of arthritis develops. This may help in future preventive strategies. The first step has to be a coordinated effort across nations and various rheumatology societies to set up working definitions and enumerate thrust areas of research for ReA.

Author contribution All co-authors contributed substantially to the concept formulation, searches of relevant articles, and revisions. They approve the final version of the manuscript and take full responsibility for all aspects of the work.

\section{Declarations}

Conflict of interest SA has received honorarium as speaker from Pfizer, DrReddy's, Cipla, and Novartis (outside of the current work). All other authors declare no competing interests.

\section{References}

1. García-Kutzbach A, Chacón-Súchite J, García-Ferrer H, Iraheta I (2018) Reactive arthritis: update 2018. Clin Rheumatol 37:869874. https://doi.org/10.1007/s10067-018-4022-5

2. Hannu T, Inman R, Granfors K, Leirisalo-Repo M (2006) Reactive arthritis or post-infectious arthritis? Best Pract Res Clin Rheumatol 20:419-433. https://doi.org/10.1016/j.berh.2006.02.003
3. Rosenbaum JT (2016) Evolving diagnostic criteria for axial spondyloarthritis. Ocul Immunol Inflamm 24:445-449. https://doi.org/ 10.3109/09273948.2016.1158277

4. Rudwaleit M, van der Heijde D, Landewé R et al (2011) The Assessment of SpondyloArthritis International Society classification criteria for peripheral spondyloarthritis and for spondyloarthritis in general. Ann Rheum Dis 70:25-31. https://doi.org/10. 1136/ard.2010.133645

5. Dougados M, van der Linden S, Juhlin R et al (1991) The European Spondylarthropathy Study Group preliminary criteria for the classification of spondylarthropathy. Arthritis Rheum 34:1218-1227

6. Kaarela K, Jäntti JK, Kotaniemi KM (2009) Similarity between chronic reactive arthritis and ankylosing spondylitis.A 32-35-year follow-up study. Clin Exp Rheumatol 27:325-328

7. Misra R, Ahmed S, Chaudhury A et al (2018) THU0269 Development of ankylosing spondylitis in patients with reactive arthritis and peripheral spondyloarthropathy: hospital based study in north India. Ann Rheum Dis 77:353-353. https://doi.org/10.1136/annrh eumdis-2018-eular.6558

8. Gasparyan AY, Ayvazyan L, Blackmore H, Kitas GD (2011) Writing a narrative biomedical review: considerations for authors, peer reviewers, and editors. Rheumatol Int 31:1409-1417. https://doi. org/10.1007/s00296-011-1999-3

9. Chen Q, Allot A, Lu Z (2020) Keep up with the latest coronavirus research. Nature 579:193-193. https://doi.org/10.1038/ d41586-020-00694-1

10. Antonio I-G, Jose FR, Rafael V, Eric LM (2004) A brief history of Stoll-Brodie-Fiessinger-Leroy syndrome (Reiters syndrome) and reactive arthritis with a translation of Reiters original 1916 article into English. Curr Rheumatol Rev 1:71-79

11. Panush RS, Paraschiv D, Dorff REN (2003) The tainted legacy of Hans Reiter. Semin Arthritis Rheum 32:231-236. https://doi.org/ 10.1053/sarh.2003.49997

12. Brodie BC (1819) Pathological and surgical observations on diseases of the joints. Edinb Med Surg J 15:440-446

13. Ahvonen P, Sievers K, Aho K (1969) Arthritis associated with Yersinia enterocolitica infection. Acta Rheumatol Scand 15:232 253. https://doi.org/10.3109/rhe1.1969.15.issue-1-4.32

14. Gordon FB, Quan AL, Steinman TI, Philip RN (1973) Chlamydial isolates from Reiter's syndrome. Br J Vener Dis 49:376-380. https://doi.org/10.1136/sti.49.4.376

15. Colmegna I, Cuchacovich R, Espinoza LR (2004) HLA-B27-associated reactive arthritis: pathogenetic and clinical considerations. Clin Microbiol Rev 17:348-369. https://doi.org/10.1128/CMR. 17.2.348-369.2004

16. Kuipers JG, Köhler L, Zeidler H (1999) Reactive or infectious arthritis. Ann Rheum Dis 58:661-664. https://doi.org/10.1136/ ard.58.11.661

17. Ahmed S, Padhan P, Misra R, Danda D (2021) Update on poststreptococcal reactive arthritis: narrative review of a forgotten disease. Curr Rheumatol Rep 23:19. https://doi.org/10.1007/ s11926-021-00982-3

18. Braun J, Kingsley G, van der Heijde D, Sieper J (2000) On the difficulties of establishing a consensus on the definition of and diagnostic investigations for reactive arthritis. Results and discussion of a questionnaire prepared for the 4th International Workshop on Reactive Arthritis, Berlin, Germany, July 3-6, 1999. J Rheumatol 27:2185-2192

19. Selmi C, Gershwin ME (2014) Diagnosis and classification of reactive arthritis. Autoimmun Rev 13:546-549. https://doi.org/ 10.1016/j.autrev.2014.01.005

20. Zeidler H, Hudson AP (2021) Reactive arthritis update: spotlight on new and rare infectious agents implicated as pathogens. Curr Rheumatol Rep 23:53. https://doi.org/10.1007/ s11926-021-01018-6 
21. Townes JM (2010) Reactive arthritis after enteric infections in the United States: the problem of definition. Clin Infect Dis 50:247254. https://doi.org/10.1086/649540

22. Courcoul A, Brinster A, Decullier E et al (2018) A bicentre retrospective study of features and outcomes of patients with reactive arthritis. Joint Bone Spine 85:201-205. https://doi.org/10.1016/j. jbspin.2017.01.013

23. Tuompo R, Lääveri T, Hannu T et al (2020) Reactive arthritis and other musculoskeletal symptoms associated with acquisition of diarrhoeagenic Escherichia coli (DEC). Ann Rheum Dis 79:605-611. https://doi.org/10.1136/annrheumdis-2019-216736

24. Hayes KM, Hayes RJP, Turk MA, Pope JE (2019) Evolving patterns of reactive arthritis. Clin Rheumatol 38:2083-2088. https:// doi.org/10.1007/s10067-019-04522-4

25. López-Medina C, Molto A, Sieper J et al (2021) Prevalence and distribution of peripheral musculoskeletal manifestations in spondyloarthritis including psoriatic arthritis: results of the worldwide, cross-sectional ASAS-PerSpA study. RMD Open 7:e001450. https://doi.org/10.1136/rmdopen-2020-001450

26. Thomas KN, Anuja AK, Gupta L (2020) Clinical profile of adults and children with reactive arthritis in India - A cohort study. Indian J Rheumatol 15:304-309. https://doi.org/10.4103/injr.injr_ 126_20

27. Pogreba-Brown K, Austhof E, Tang X et al (2021) Enteric pathogens and reactive arthritis: systematic review and meta-analyses of pathogen-associated reactive arthritis. Foodborne Pathog Dis 18:627-639. https://doi.org/10.1089/fpd.2020.2910

28. Coath FL, Mackay J, Gaffney JK (2021) Axial presentation of reactive arthritis secondary to Covid-19 infection. Rheumatology (Oxford) keab009. https://doi.org/10.1093/rheumatology/keab009

29. Sureja NP, Nandamuri D (2021) Reactive arthritis after SARSCoV-2 infection. Rheumatol Adv Pract 5:rkab001. https://doi.org/ 10.1093/rap/rkab001

30. Cincinelli G, Di Taranto R, Orsini F et al (2021) A case report of monoarthritis in a COVID-19 patient and literature review: simple actions for complex times. Medicine (Baltimore) 100:e26089. https://doi.org/10.1097/MD.0000000000026089

31. Saricaoglu EM, Hasanoglu I, Guner R (2021) The first reactive arthritis case associated with COVID-19. J Med Virol 93:192193. https://doi.org/10.1002/jmv.26296

32. Liew IY, Mak TM, Cui L et al (2020) A case of reactive arthritis secondary to coronavirus disease 2019 infection. J Clin Rheumatol 26:233. https://doi.org/10.1097/RHU.0000000000001560

33. Ono K, Kishimoto M, Shimasaki T et al (2020) Reactive arthritis after COVID-19 infection. RMD Open 6:e001350. https://doi.org/ 10.1136/rmdopen-2020-001350

34. Talarico R, Stagnaro C, Ferro F et al (2020) Symmetric peripheral polyarthritis developed during SARS-CoV-2 infection. Lancet Rheumatol 2:e518-e519. https://doi.org/10.1016/S26659913(20)30216-2

35. Gasparotto M, Framba V, Piovella C et al (2021) PostCOVID-19 arthritis: a case report and literature review. Clin Rheumatol 40:3357-3362. https://doi.org/10.1007/ s10067-020-05550-1

36. Colatutto D, Sonaglia A, Zabotti A et al (2021) Post-COVID-19 arthritis and sacroiliitis: natural history with longitudinal magnetic resonance imaging study in two cases and review of the literature. Viruses 13:1558. https://doi.org/10.3390/v13081558

37. Salvatierra J, Martínez-Peñalver D, Salvatierra-Velasco L (2020) CoVid-19 related dactyitis. Joint Bone Spine 87:660. https://doi. org/10.1016/j.jbspin.2020.06.009

38. Yokogawa N, Minematsu N, Katano H, Suzuki T (2020) Case of acute arthritis following SARS-CoV-2 infection. Ann Rheum Dis Annrheumdis-2020-218281. https://doi.org/10.1136/annrh eumdis-2020-218281
39. Danssaert Z, Raum G, Hemtasilpa S. Reactive arthritis in a 37-year-old female with SARS-CoV2 infection. Cureus 12:e9698. https://doi.org/10.7759/cureus.9698

40. Schenker HM, Hagen M, Simon D et al (2021) Reactive arthritis and cutaneous vasculitis after SARS-CoV-2 infection. Rheumatology (Oxford) 60:479-480. https://doi.org/10.1093/rheum atology/keaa689

41. Houshmand H, Abounoori M, Ghaemi R, et al (2020) Ten-yearold boy with atypical COVID-19 symptom presentation: a case report. Clin Case Rep [Online ahead of print]. https://doi.org/ $10.1002 / \mathrm{ccr} 3.3521$

42. Jali I (2020) Reactive arthritis after COVID-19 infection. Cureus 12:e11761. https://doi.org/10.7759/cureus.11761

43. Di Carlo M, Tardella M, Salaffi F (2021) Can SARS-CoV-2 induce reactive arthritis? Clin Exp Rheumatol 39(Suppl 128):25-26

44. Hønge BL, Hermansen M-LF, Storgaard M (2021) Reactive arthritis after COVID-19. BMJ Case Rep 14:e241375. https://doi.org/ 10.1136/bcr-2020-241375

45. Sinaei R, Pezeshki S, Parvaresh S et al (2021) Post SARS-CoV-2 infection reactive arthritis: a brief report of two pediatric cases. Pediatr Rheumatol Online J 19:89. https://doi.org/10.1186/ s12969-021-00555-9

46. Shokraee K, Moradi S, Eftekhari T et al (2021) Reactive arthritis in the right hip following COVID-19 infection: a case report. Trop Dis Travel Med Vaccines 7:18. https://doi.org/10.1186/ s40794-021-00142-6

47. Kocyigit BF, Akyol A (2021) Reactive arthritis after COVID-19: a case-based review. Rheumatol Int 41:2031-2039. https://doi.org/ 10.1007/s00296-021-04998-x

48. Baimukhamedov C, Barskova T, Matucci-Cerinic M (2021) Arthritis after SARS-CoV-2 infection. Lancet Rheumatol 3:e324e325. https://doi.org/10.1016/S2665-9913(21)00067-9

49. Derksen VFAM, Kissel T, Lamers-Karnebeek FBG, et al (2021) Onset of rheumatoid arthritis after COVID-19: coincidence or connected? Ann Rheum Dis Annrheumdis 2021-219859. https:// doi.org/10.1136/annrheumdis-2021-219859

50. Roongta R, Chattopadhyay A, Ghosh A (2021) Correspondence on "Onset of rheumatoid arthritis after COVID-19: coincidence or connected?” Ann Rheum Dis Annrheumdis 2021-220479. https:// doi.org/10.1136/annrheumdis-2021-220479

51. Velikova T, Georgiev T (2021) SARS-CoV-2 vaccines and autoimmune diseases amidst the COVID-19 crisis. Rheumatol Int 41:509-518. https://doi.org/10.1007/s00296-021-04792-9

52. An Q-J, Qin D-A, Pei J-X (2021) Reactive arthritis after COVID19 vaccination. Hum Vaccin Immunother 17:2954-2956. https:// doi.org/10.1080/21645515.2021.1920274

53. Unal Enginar A (2021) Arthritis following COVID-19 vaccination: report of two cases. Int Immunopharmacol 101:108256. https://doi.org/10.1016/j.intimp.2021.108256

54. (2022) SARS-COV-2-vaccine-inactivated-Sinovac-Biotech. Reactions Weekly 1890:229-229. https://doi.org/10.1007/ s40278-022-09226-x

55. Baimukhamedov C (2021) Arthritis of the left elbow joint after vaccination against SARS-CoV-2 infection. Int $\mathrm{J}$ Rheum Dis 24:1218-1220. https://doi.org/10.1111/1756-185X.14202

56. Baimukhamedov C, Makhmudov S, Botabekova A (2021) Seropositive rheumatoid arthritis after vaccination against SARSCoV-2 infection. Int J Rheum Dis 24:1440-1441. https://doi.org/ 10.1111/1756-185X.14220

57. Ahmed S, Zimba O, Gasparyan AY (2021) COVID-19 and the clinical course of rheumatic manifestations. Clin Rheumatol 40:2611-2619. https://doi.org/10.1007/s10067-021-05691-x

58. Roncati L, Gianotti G, Gravina D et al (2021) Carpal, cubital or tarsal tunnel syndrome after SARS-CoV-2 infection: A causal link? Med Hypotheses 153:110638. https://doi.org/10.1016/j. mehy.2021.110638 
59. Terracina KA, Tan FK (2021) Flare of rheumatoid arthritis after COVID-19 vaccination. The Lancet Rheumatology 3:e469-e470. https://doi.org/10.1016/S2665-9913(21)00108-9

60. Cherian S, Paul A, Ahmed S et al (2021) Safety of the ChAdOx1 nCoV-19 and the BBV152 vaccines in 724 patients with rheumatic diseases: a post-vaccination cross-sectional survey. Rheumatol Int 41:1441-1445. https://doi.org/10.1007/s00296-021-04917-0

61. Li X, Tong X, Yeung WWY et al (2021) Two-dose COVID-19 vaccination and possible arthritis flare among patients with rheumatoid arthritis in Hong Kong. Ann Rheum Dis. https://doi.org/ 10.1136/annrheumdis-2021-221571

62. Marks M, Marks JL (2016) Viral arthritis Clin Med (Lond) 16:129-134. https://doi.org/10.7861/clinmedicine.16-2-129

63. Chen Y-L, Jing J, Mo Y-Q et al (2018) Presence of hepatitis B virus in synovium and its clinical significance in rheumatoid arthritis. Arthritis Res Ther 20:130. https://doi.org/10.1186/ s13075-018-1623-y

64. Kemmer NM, Sherman KE (2010) Hepatitis C-related arthropathy: diagnostic and treatment considerations. J Musculoskelet Med 27:351-354

65. Tritsch SR, Encinales L, Pacheco N et al (2020) Chronic joint pain 3 years after Chikungunya virus infection largely characterized by relapsing-remitting symptoms. J Rheumatol 47:1267-1274. https://doi.org/10.3899/jrheum.190162

66. Kobayashi S, Taniguchi Y, Kida I, Tamura N SARS-CoV2-triggered acute arthritis: viral arthritis rather than reactive arthritis. Journal of Medical Virology n/a: https://doi.org/10.1002/jmv. 27229

67. Novelli L, Motta F, Ceribelli A et al (2021) A case of psoriatic arthritis triggered by SARS-CoV-2 infection. Rheumatology (Oxford) 60:e21-e23. https://doi.org/10.1093/rheumatology/keaa6 91

68. Amaral JK, Bilsborrow JB, Schoen RT (2020) Chronic Chikungunya arthritis and rheumatoid arthritis: what they have in common. Am J Med 133:e91-e97. https://doi.org/10.1016/j.amjmed.2019. 10.005

69. Takahashi Y, Murai C, Shibata S et al (1998) Human parvovirus B19 as a causative agent for rheumatoid arthritis. Proc Natl Acad Sci USA 95:8227-8232

70. Smatti MK, Cyprian FS, Nasrallah GK et al (2019) Viruses and autoimmunity: a review on the potential interaction and molecular mechanisms. Viruses 11:762. https://doi.org/10.3390/v11080762

71. MacDonald L, Alivernini S, Tolusso B et al (2021) COVID-19 and RA share an SPP1 myeloid pathway that drives PD-L1+ neutrophils and CD14+ monocytes. JCI Insight 6:147413. https://doi. org/10.1172/jci.insight. 147413

72. Suhrbier A (2019) Rheumatic manifestations of chikungunya: emerging concepts and interventions. Nat Rev Rheumatol 15:597611. https://doi.org/10.1038/s41584-019-0276-9
73. Weisberg SP, Connors TJ, Zhu Y et al (2021) Distinct antibody responses to SARS-CoV-2 in children and adults across the COVID-19 clinical spectrum. Nat Immunol 22:25-31. https:// doi.org/10.1038/s41590-020-00826-9

74. Ng KW, Faulkner N, Cornish GH et al (2020) Preexisting and de novo humoral immunity to SARS-CoV-2 in humans. Science 370:1339-1343. https://doi.org/10.1126/science.abe1107

75. Bonelli M, Dalwigk K, Platzer A et al (2019) IRF1 is critical for the TNF-driven interferon response in rheumatoid fibroblast-like synoviocytes. Exp Mol Med 51:1-11. https://doi.org/10.1038/ s12276-019-0267-6

76. Zhou Y, Han T, Chen J et al (2020) Clinical and autoimmune characteristics of severe and critical cases of COVID-19. Clin Transl Sci 13:1077-1086. https://doi.org/10.1111/cts.12805

77. Dotan A, Muller S, Kanduc D et al (2021) The SARS-CoV-2 as an instrumental trigger of autoimmunity. Autoimmun Rev 20:102792. https://doi.org/10.1016/j.autrev.2021.102792

78. Jubber A, Moorthy A (2021) Reactive arthritis: a clinical review. J R Coll Physicians Edinb 51:288-297. https://doi.org/10.4997/ JRCPE.2021.319

79. Kuschner Z, Ortega A, Mukherji P (2021) A case of SARS-CoV2-associated arthritis with detection of viral RNA in synovial fluid. J Am Coll Emerg Physicians Open 2:e12452. https://doi. org/10.1002/emp2.12452

80. Yokogawa N, Minematsu N, Katano H, Suzuki T (2021) Case of acute arthritis following SARS-CoV-2 infection. Ann Rheum Dis 80:e101-e101. https://doi.org/10.1136/annrheumdis-2020-218281

81. Grassi M, Giorgi V, Nebuloni M et al (2021) SARS-CoV-2 in the knee joint: a cadaver study. Clin Exp Rheumatol. https://pubmed. ncbi.nlm.nih.gov/34665699/

82. Aguila Maldonado R, Ruta S, Valuntas ML, García M (2017) Ultrasonography assessment of heel entheses in patients with spondyloarthritis: a comparative study with magnetic resonance imaging and conventional radiography. Clin Rheumatol 36:18111817. https://doi.org/10.1007/s10067-017-3723-5

83. Jacobson JA, Girish G, Jiang Y, Resnick D (2008) Radiographic evaluation of arthritis: inflammatory conditions. Radiology 248:378-389. https://doi.org/10.1148/radiol.2482062110

84. Gandjbakhch F, Terslev L, Joshua F et al (2011) Ultrasound in the evaluation of enthesitis: status and perspectives. Arthritis Res Ther 13:R188. https://doi.org/10.1186/ar3516

85. Watad A, De Marco G, Mahajna H et al (2021) Immune-mediated disease flares or new-onset disease in 27 subjects following mRNA/DNA SARS-CoV-2 vaccination. Vaccines 9:435. https:// doi.org/10.3390/vaccines9050435

Publisher's note Springer Nature remains neutral with regard to jurisdictional claims in published maps and institutional affiliations. 


\section{Authors and Affiliations}

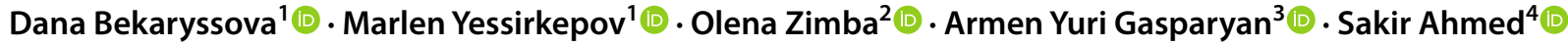

Dana Bekaryssova

bekaryssova@mail.ru

Marlen Yessirkepov

m.yessirkepov@gmail.com

Olena Zimba

zimbaolena@gmail.com

Armen Yuri Gasparyan

a.gasparyan@gmail.com

1 Department of Biology and Biochemistry, South Kazakhstan Medical Academy, Shymkent, Kazakhstan
2 Department of Internal Medicine \#2, Danylo Halytsky Lviv National Medical University, Lviv, Ukraine

3 Departments of Rheumatology and Research and Development, Dudley Group NHS Foundation Trust (Teaching Trust of the University of Birmingham, UK), Russells Hall Hospital, Dudley, West Midlands, UK

4 Department of Clinical Immunology and Rheumatology, Kalinga Institute of Medical Sciences (KIMS), KIIT University, Bhubaneswar 751024, India 